\title{
INFLUENCE OF SEX ON STUDENTS' LANGUAGE LEARNING STRATEGIES: A CRITICAL REVIEW
}

\author{
Niwayan Sukraini \\ Institut Agama Hindu Negeri Tampung Penyang Palangka Raya \\ niwayansukraini.iahntp@gmail.com
}

\begin{abstract}
Due to the importance of providing learning environment that suits the students' preference in learning a language, many studies have been conducted on the learning strategies employed by the students. Doro and Habok (2013) investigated the learning strategies of Hungarian young students learning English as a foreign language. The instrument they used was the Strategy Inventory for Language Learning (SILL) for adult. It was statistically found that the instrument was reliable and worked well with the young learners. Another result of the study was that meta-cognitive strategies were the most frequently used while compensation strategies were the least frequently employed by the students. The study also discovered that female students showed higher frequency of learning strategy use. I conducted a similar study on Indonesian young students and tried to compare the result. There will be, however, difference in the instrument to collect the data. After consulting an English teacher who teaches young students, I decided to use the modified SILL for Taiwanese children by Lan (2005). This is due to the consideration that Indonesian students might not be able to fill in the complex questionnaire as in the adult version of SILL.The findings show that Meta-cognitive strategies as the most preferred group of the six strategy categories have exactly the same means of both Doro and Habok's and my studies i.e. 3.2 and female students appeared to use language learning strategies more frequently that male students.
\end{abstract}

Keywords: learning, strategy, sex, influence, language

\section{To cite this article:}

Sukraini, N. (2021). Influence of Sex on Students' Language Learning Strategies: A Critical Review. Journal of Research on Language Education, 2(1), 37-43.

\section{INTRODUCTION}

The potential of strategies used by language learners has been an interest among many scholars despite some controversy over the basic issues. There was a concensus stated that language learning strategies used by the learners contributes signifiantly to the mastery of target language. There are many studies that explore the language learning strategies and styles and its significance of target language mastery (Mandasari \& Oktaviani, 2018; Wahyudin \& Rido, 2020; Lestari \& Wahyudin, 2020). However, this paper tried to replicate the study reported in the article entitled Language Learning Strategies in Elementary School: The Effect of Age and Gender in an EFL Context written by Katalin Doro and Anita Habok. Doro is a teacher in Department of English Language Teacher Education and Applied Linguistics, while Habok is an employee in the Institute of Education MTA-SZTE Research Group in the Development of Competencies. Both of them work for University of Szeged, Hungary.

\section{An Overview of Doro and Habok's Article Confronting the terminology}

In their article, Doro and Habok consistently use the term gender to classify students into male and female. Oxford Learner Dictionaries (2020) defines gender as "the fact of being male or female, especially when considered with reference to social and cultural differences, not differences in biology. The term gender is also used more broadly to mean a range of identities that do not necessarily fit in with the usual division between male and female." While the word sex simply means "the state of being male or female" (Oxford Learner Dictionaries (2020). Therefore, instead of gender, the term sex is more suitable with the context in Doro and Habok's paper since they do not specify the students being male and female based on social and cultural perspectives. Consequently, in this critical review, the term sex is used to refer to the variable being studied. 


\section{The importance of the subject}

Doro and Habok implicitly mentioned the importance of writing the article. They illustrated that over the last four decades, valuable insight regarding how learners comprehend and acquire their own second or foreign language teaching in or outside the classroom, has been obtained from research on language learning strategies. The authors, however, observed that there was something missing in terms of research or published literature that specifically focused on language learning strategies employed by primary school students learning English as a foreign language.

In addition, Doro and Habok quoted the statements of some scholars (such as Oxford and Bury-Stock (1995), Yilmaz (2010), and Jin-Suk and Tae-Young (2011)), conveying the need of more research on learner beliefs and strategies from various cultural and linguistic backgrounds. In order to contribute to this field, the authors conducted a study on the overall language learning strategies of a great deal of Hungarian EFL fifth and sixth graders and their strategy use according to their grade level and sex. The author, however, did not explicitly relate the cultural and linguistic variation with their research variables (i.e. sex and grade). It would have been better if they provided a clear description of how sex and grade could be the aspects of cultural and linguistic background variation.

\section{The literature review}

The review of related literature shows that the article is written based on rather up-to-date references. All of the journal articles and most of the books quoted in this article are written after the year 2001. The older references used by Doro and Habok are the ones that consists of basic underlying theories such as the books by Chamot, O'Malley, Oxford, and Rubin. The authors of this article reviewed some definitions of language learning strategy by some expert such as O’Malley and Chamot, Cohen, and Oxford. Surprisingly, the authors absurdly chose to adopt the definition by Oxford without conveying the motive behind it. A synthesized definition would be more preferable.

\section{The research objectives and methodology}

Doro and Habok specified the objectives of their research. The first purpose is to investigate whether the Strategy Inventory for Language Learning (SILL) for adult is a reliable instrument to be used for children learning English. Secondly, the research aimed at studying the overall language learning strategies used by the students as one main group. The third objective is to determine the significant differences between the fifth and sixth grades in their strategy use. The last aim is to know the significant differences in the students' strategy use according to their sex. Regarding grade and sex as two of the research variables, Doro and Habok did not clearly describe their rationale on why they included those variables.

The methodology employed in this article is an empirical study where the researchers required fifth and sixth graders to fill in questionnaire items i.e. an adapted version of the SILL for ESL or EFL learners. The researchers, however, did not provide explanation on why they used the adapted version (by other researcher i.e. Yang (2002) instead of using the original version by Oxford (1990). Another odd thing is, in all sections of the article (except in the instrument section), the researcher kept mentioning that they used the original version of SILL by Oxford (1990). This can come across as misleading to the readers.

\section{The findings and implications}

The findings show that the SILL for adults worked well with Hungarian young students. The researchers stressed that the reliability of the instrument was because it was translated into Hungarian language. The respondents as one group showed more frequent use of meta-cognitive strategies. Regarding the different grades, there were no significant differences in the students' learning strategy use. The study also discovered that female students showed higher frequency of learning strategy use.

The authors seemed to only describe, not discuss the findings. They should have explored what might be the causes of the findings turning out like that. For example, when the result shows that female students employed more frequent strategy use than male students, the authors could have stated that it might be because female students are more meticulous in nature.

In their article, Doro and Habok states "The combination of age, language background and methodology chosen for this study has not been investigated earlier. Therefore, result provides new insight into early strategy use of young foreign language learners". This statement shows that the authors claims to have contributed to new knowledge. In reality, the difference from the previous research is only the background language i.e. Hungarian language. The other variables such as students' age and methodology (the use of the SILL) have been studied by a great number of researchers. 
Doro and Habok realized the strength as well as the shortcomings of their study. The study has proven that the adult version of the SILL is reliable to be used by the students of eleven years old to do self-reporting. One of the weaknesses of the study is related to the homogeneity of the subjects' educational background. All of the subjects came from similar public elementary schools of the same region. The implication of this reality is that the results of the experiment are only valid for this specific student population. Another limitation is that the results do not necessarily reflect the strategy use related to certain task types used in the classroom. Therefore, the authors pointed out that overgeneralization of the results should be avoided.

\section{RESEARCH METHOD}

The research by Doro and Habok inspired the researcher to do a similar study which eventually led to an empirical review of the article. There are, however, some differences between this research compared to theirs regarding the subjects and the instrument to collect the data. The subjects of Doro and Habok's research were Hungarian fifth and sixth graders while this study required responses from fifth grade Indonesian students in an EFL context. The sixth graders were not accessible because they were preparing for National Examination. The details will be explained in the next section.

As for the instrument, Doro and Habok took the result of another research i.e. by Pinter (2006) -which concluded that children of age 10 and 11 can think logically, organize their thoughts and focus on a wide range of cognitive tasks- and their personal experience working with Hungarian 10- and 11-year-old students, as the primary reasons of employing the adult version of the SILL. However, the situation is different in Indonesia (Sinaga and Oktaviani, 2020). After consulting an English teacher who teaches young students, the researcher decided to use the modified SILL for Taiwanese children by Lan (2006). This is due to the consideration that Indonesian students might not be able to fill in the complex questionnaire as in the adult version of SILL.

As the researcher was interested in conducting a similar study on Indonesian EFL learners and in seeking to compare the result, the research questions are formulated as follows.

1. What is the overall language learning strategy use of the fifth-grade students?

2. Are there significant differences between the male and female students in their language learning strategy use?

\section{Participants}

Twenty five students of the fifth grade of the Lab UM Primary School gave responses to the questionnaire prepared. Ten of the respondents were females while the other fifteen students were male. The students belonged to International Class Program (ICP) -where English was primarily used as the language of the classroom instruction- and have learned English for roughly five years. Prior to administering the questionnaire, the researcher strived for obtaining consent from the university educational laboratory unit (UPT P2LP) and the headmaster of Lab UM Primary School. The reason why the participants was choose because even though it is ICP, the students have learned English in pretty much the same length as the other primary school students have.

\section{Instruments}

In contrast to Doro and Habok's study, -in which the adult version of the SILL was employed- I used the SILL for Taiwanese children proposed by Lan (2006). The questionnaire consisted of thirty-one statements which are categorized into six parts as listed in the Appendix 1.

To make sure that the respondents could clearly understand the statements, the questionnaire was translated to Indonesian language and a modification was made. The modification was in the form of more detailed items by giving clear examples. The items were evaluated using a five-point Likert scale with the following values.

1. Never to almost never,

2. Usually not,

3. Sometimes,

4. Often, and

5. Always or almost always

\section{FINDINGS AND DISCUSSION}

The subjects of the study were asked to respond to a five-point Likert scale items to show which language learning strategies they use more often. Just like the in Doro and Habok's research, the students' responses of my research were computer-coded and processed with the Statistical Package for the Social Science (SPSS). The results are discussed below. 


\section{Overall strategy use}

Table 1 illustrates the overall language learning strategy use in all respondents. Memory strategies were the least frequently used by the students with mean only 2.33. Compensation, cognitive, affective, and social strategies held the second to fourth positions in term of frequency of use with means respectively 2.65, 2.88, 2.93, and 2.96. Meta-cognitive strategies (Mean=3.28) are shown to be the most preferred strategies.

These data indicates consistency with the results of Doro and Habok's study. Meta-cognitive strategies as the most preferred group of the six strategy categories have exactly the same means of both studies i.e. 3.2. The means of compensation, cognitive and affective strategy use are also identical between the two studies $(\mathrm{M}=2.6$, 2.8, and 2.9). The differences are only on the means of memory and social strategies and on compensation strategies being the least preferred strategies in Doro and Habok's study, while in my study, memory strategies are.

Table 1. Summary of Language Learning Strategy Use in All Respondents

\begin{tabular}{lc}
\hline Strategy sub-scales & $\begin{array}{c}\text { All respondents } \\
\mathbf{N = 2 5}\end{array}$ \\
\cline { 2 - 2 } & Mean \\
\hline Memory & 2.33 \\
Cognitive & 2.88 \\
Compensation & 2.65 \\
Meta-cognitive & 3.28 \\
Affective & 2.93 \\
Social & 2.96 \\
\hline
\end{tabular}

These data indicates consistency with the results of Doro and Habok's study. Meta-cognitive strategies as the most preferred group of the six strategy categories have exactly the same means of both studies i.e. 3.2. The means of compensation, cognitive and affective strategy use are also identical between the two studies $(\mathrm{M}=2.6$, 2.8, and 2.9). The differences are only on the means of memory and social strategies and on compensation strategies being the least preferred strategies in Doro and Habok's study, while in my study, memory strategies are.

The major similarity between the two studies was meta-cognitive being the most frequently used strategies and with identical means. This is probably because the teaching of English in Hungary and Indonesia are similar i.e. students are encouraged to coordinate their language learning process by frequently doing planning and selfmonitoring. The reason might be that the English language instructors in both countries are aware of the importance of training meta-cognitive strategies. Goh (2002) argues that learners' meta-cognitive awareness is related to effective learning in all learning context. In addition, as quoted from O'malley at al (1985), learners who do not employ meta-cognitive approaches have no direction or ability in monitor their progress, accomplishment, and future learning direction.

\section{Strategy use according to sex}

Table 2. Summary of Language Learning Strategy Use by Sex

\begin{tabular}{lcc}
\hline \multirow{2}{*}{ Strategy sub-scales } & Boys & Girls \\
& $\mathbf{N = 1 4}$ & N=10 \\
\cline { 2 - 3 } & Mean & Mean \\
\hline Memory & 2.14 & 2.64 \\
Cognitive & 3.05 & 3.15 \\
Compensation & 2.4 & 3.1 \\
Meta-cognitive & 3.1 & 3.54 \\
Affective & 2.78 & 3.13 \\
Social & 2.69 & 3.3 \\
\hline
\end{tabular}

Table 2 illustrates the mean of each language learning strategy employed by male as well as female students. As shown in the table, the female students appeared to use language learning strategies more frequently that male students. The mean differences range from 0.1 to 0.7 . The smallest difference among the strategies was cognitive strategies $($ male $=3.05$; female $=3.15)$ while the largest one is compensation strategies $($ male $=2.4$; female $=3.1)$.

Saville-Troike (2006) states "The tendency of females doing better than males in language learning is a widespread belief among the society of the western cultures. It is a perhaps a social construct". The female students (in this study) employing more compensation strategies might be because they are more determined and hardworking in term of trying to understand their interlocutors and to make themselves understood. In the 
endeavors, female students might want to guess an unknown word or phrase by looking at the whole sentence, use gesture when they do not know how to say it, ask help when they forget a word or phrase, and use alternatives of saying something.

\section{CONCLUSION}

The result of this study supports Doro and Habok's findings and indicates consistency of meta-cognitive strategies as the most frequently used by English language learners. Other language learning strategies such as compensation, cognitive and affective strategy use are identical between the two studies. The consistent findings are probably because the instruments of both studies were translated into the students' native language. Therefore, I suggest that other researchers interested in conducting similar studies choose the appropriate instrument and translate it into students' mother tongue.

Since learning strategies can actually be taught (William and Burden, 1997), another suggestion is for teachers to train language learning strategies to their students. Teaching learning strategies can increase student motivation in two main ways: by increasing students' confidence in their own learning ability and by providing students with specific techniques for successful language learning (Wahyudin, 2017, 2018). In addition, students who have learned how and when to use learning strategies become more self-reliant and better able to learn independently. The purpose of employing strategies by learners is to make learning more effective and long lasting (Mitchell \& Myles, 2002). Lastly, it is recommended that teachers always include both male and female students in groupwork. This will promote learning opportunity for male students to observe how female students use their learning strategies.

\section{REFERENCES}

Chamot, A.U. (2008). Strategy Instruction and Good Language Learners. In C. Griffiths (ed.), Lessons from Good Language Learners (pp.266-281). Cambridge: Cambridge University Press.

Cohen, A.D. (2007). Coming to terms with language strategies: Surveying the experts. In D.C. Cohen \& E.M. Macaro (Eds). Language Learner Strategies, pp.29-45. Oxford, UK: Oxford University Press.

Doro, K. \& Habok, A. (2013). Language Learning Strategies in Elementary School: The Effect of Age and Gender in an EFL Context. Journal of Linguistics and Language Teaching. 4(2): 25-37.

Goh, C. (2002). Exploring Listening Comprehension Tactics and Their Interaction Patterns. System. 30(2):185-206.

Jin-Suk \& Tae-Young (2011). The L2 Motivational Self System and Perceptual Learning Styles of Chinese, Japanese, Korean, and Swedish Students.Retrieved from: https://www.researchgate.net/publication/285827083_The_L2_Motivational_Self_System_and_Perceptual_Learning _Styles_of_Chinese_Japanese_Korean_and_Swedish_StudentsLan, R. L. 2006. Language Learning Strategies Profiles of EFL Elementary School Students in Taiwan. Unpublished Doctoral Dissertation. University of Maryland.

Lestari, M. \& Wahyudin, AY. (2020). Language learning strategies of undergraduate EFL students. Journal of English Language Teaching and Learning 1 (1), 25-30.

Mandasari, B., \& Oktaviani, L. English language learning strategies: an exploratory study of management and engineering students. Premise: Journal of English Education and Applied Linguistics 7 (2), 61-78.

Mitchell, R., \& Myles, F. (2002). Second Language Learning Theories. London: Arnold.

O’Malley, J. M., Chamot, A. U., Stewner-Manzanares, G., Russo, R., \& Kupper, L. (1985). Learning strategy applications with students of English as a second language. TESOLQuarterly. 19: 285-296.

Oxford, R. L. (1990). Language learning strategies: What every teacher should know. New York: Newbury House.

Oxford, R. L. \& Bury-Stock (1995). Assessing language learning strategies worldwide with the ESL/EFL version of the strategy inventory for language learning (SILL). System, 37(3), 418-433.

Pinter, A. (2006). Teaching Young Language Learners. United Kingdom: Oxford University Press.

Rubin, J. (1981). Study of cognitive progresses in second language learning. Applied Linguistics, 11(2), 117-131.

Sinaga, R. R. F. \& Oktaviani, L. (2020). The Implementation of Fun Fishing to Teach Speaking for Elementary School Students. Journal of English Language Teaching and Learning, 1(1), 1-6.

Saville-Troike (2006). Introducing Second Language Acquisition. Cambridge: Cambridge University Press.

Wahyudin, A. Y. (2017). The Effect of Project-Based Learning on L2 Spoken Performance of Undergraduate Students in English for Business Class. The Ninth International Conference on Applied Linguistics (Conaplin 9), 42-46.

Wahyudin, A. Y. (2018). The impact of online peer feedback on EFL students'writing at tertiary level. BAHTERA: Jurnal Pendidikan Bahasa dan Sastra 17 (1), 1-10

Wahyudin, A. Y. \& Rido, A. (2020). Perceptuals learning styles preferences of international Master's students in Malaysia. BAHTERA: Jurnal Pendidikan Bahasa Dan Sastra 19 (1), 169-183.

Williams, M., \& Burden, R. L. (1997). Psychology for Language Teachers: A Social Constructivist Approach. UK: Cambridge University Press.

Yang, N. (2002). Integrating portfolios into learning strategy-based instruction for EFL college students. IRAL, International Review of Applied Linguistics in Language Teaching, 41(4), 293-325.

Yilmaz, C. (2011). Teachers' perceptions of self-efficacy, English proficiency, and instructional strategies. Social Behavior and Personality: An international journal, 39(1), 91-100. 


\section{APPENDIX}

Appendix 1: Questionnaire (Proposed by Lan (2005))

Part A (Memory: restoring and retrieving information)

1. I associate new English words with what I already know (for example, when I learn the word computer, I associate what I already know about computer).

2. I make a drawing, either in my head or on paper, to help me remember a new word (for example, when I learn the word bike, I picture a bike in my head).

3. I learn new words in sentences.

4. I use flash cards to memorize new words

5. I review often.

6. I often review newly learned vocabulary or expressions by repeatedly writing.

7. I often review newly learned vocabulary or expressions by repeatedly mouthing.

Part B (Cognitive: comprehending and producing the element of English language)

8. When I speak in English, I try to imitate English-speaking people, in order to pronounce the words correctly.

9. I often practice English alphabet sounds.

10. I often watch TV in English or I listen to English tapes or CDs.

11. I read books in English (for example, English story books)

12. I work with English computer programs.

13. I try to find opportunities outside of school (tutoring or cram schools) to practice my English.

14. I find similarities in pronunciation between Chinese and English (for example, the word card sounds similar to the Chinese word $\mathrm{Ka}$ ).

15. I make an effort to understand the sense of what I read or what I hear without translating word for word.

16. I try to discover grammar rules of the English language (for example, using is for singular and are for plural).

Part C (Compensation: coping with the inadequacy of English language knowledge)

17. When I hear or read a new word in English, I try to guess the meaning by looking at the rest of the sentence.

18. When I have trouble making myself understood in English, I use gestures to express what I want to say.

19. When I don't know a word in English, I ask for help.

20. When I can't find an expression in English, I try to find another way to say what I mean (for example, using words or phrases that I already know, like using big cat for the word tiger).

Part D (Metacognitive: organizing the language learning process)

21. I organize my time to study English (not just when there is a test).

22. I look for occasions to speak English.

23. When someone speaks to me in English, I listen attentively.

24. I am concerned about my progress in learning English (for example, concerning and understanding if I have learned what I am supposed to and see if I have made progress)

25. I analyse the errors I have made and try not to repeat them.

Part E (Affective: emotion and attitude toward language learning process)

26. Whenever I am stressed by the idea of speaking English, I try to relax.

27. I will still encourage myself to speak English even if I am afraid to make mistakes.

28. When I succeed, I reward myself (for example, taking a break or doing things I enjoy or treat myself to something good to eat).

Part F (Social: interaction with others during language learning process)

29. If I don't understand what is said to me in English, I ask the person to help me by speaking slowly, repeating, or clarifying what has been said.

30. I practice English with my parents, sibling (or other family members) or my classmates.

31. I am interested in and willing to learn the culture of English-speaking countries (for example America or England). 


\section{BIOGRAPHY OF AUTHOR}

Niwayan Sukraini hold a Master's Degree in English Language Teaching. Currently, she works as a lecturer at Institut Agama Hindu Negeri Tampung Penyang Palangka Raya. Her research interests include Teaching English as a Foreign Language, Second Language Acquisition, and English for Specific Purposes. 